\title{
CYTOTOXICITY OF AROMATIC COMPOUND FROM AN ENDOPHYTIC FUNGUS, CLADOSPORIUM SP. EN-S01
}

\section{R. R. INDRY NOVIARIN EXAMINATI, ASRI PENI WULANDARI, DESI HARNETI PUTRI HUSPA, PONIAH ANDAYANINGSIH}

Faculty of Mathematics and Natural Sciences Universitas, Padjadjaran, Indonesia

Email: examinati@outlook.com

Received: 10 Jul 2018, Revised and Accepted: 07 Sep 2018

\begin{abstract}
Objective: Endophytes have the potential to synthesize various bioactive secondary metabolites. The aims of the study were to isolate the major compound from endophytic Cladosporium sp. EN-S01., identify its function group, then evaluate its cytotoxicity.

Methods: The endophytic fungus was grown in potato dextrose broth and extracted using ethyl acetate. Secondary metabolites were isolated by chromatographic separation and re-crystallization, and function group was determined by infrared spectroscopy. In vitro cytotoxicity was evaluated
\end{abstract} by the prestoblue assay.

Result: The isolated aromatic compound evaluated by prestoblue assay against breast cancer cell line MCF-7 showed cytotoxicity with IC 50 value of $746,03 \mathrm{ppm}$.

Conclusion: Our findings indicate this aromatic compound might be useful lead compounds to develop cytotoxic drugs.

Keywords: Cytoxicity, Cladosporium, Endophytic, Fungus, Prestoblue, Aromatic

(C) 2018 The Authors. Published by Innovare Academic Sciences Pvt Ltd. This is an open access article under the CC BY license (http://creativecommons.org/licenses/by/4.0/) DOI: http://dx.doi.org/10.22159/ijcpr.2018v10i6.30964

\section{INTRODUCTION}

Cancer is a genomic disease characterized by uncontrolled cell proliferation and can destroy body tissues. This disease ranks second cause of death after heart disease. The most common type of cancer in women is breast cancer [1]. Until now, cancer can be treated surgically, radiation therapy, hormones, target proteins or chemotherapy [2]. The treatment is not yet fully effective because it still affects normal cells. The search for more effective cancer treatment is done using natural chemical compounds that have cytotoxic activity.

This study will use endophytic fungus isolates from Cladosporium sp. EN-S01 which is isolated from macroalgae Sargassum cinereum. Preliminary tests have been conducted to evaluate the potency of this crude extract of fungus as an anticancer candidate. Breast cancer cell cytotoxicity testing was carried out on MCF-7 cell lines because these cell lines are very stable and can represent most invasive breast cancer cells. Wulandari et al. (2018) proved that the crude extract with fermented ethyl acetate solvent from Cladosporium sp. EN-S01 shows the potential for cytotoxic activity against MCF-7 breast cancer cell lines with $\mathrm{IC}_{50}$ values of $8.46 \mu \mathrm{g} / \mathrm{ml}$ in very active category [3].

Important stages in the process of searching for new drugs (new drug discovery) in the fields of medical biotechnology and molecular biology are the discovery of drug molecules derived from plants, animals, and microorganisms by isolating and identifying the structure of pure compounds. Knowledge of the structure of pure compounds facilitates the study of lead compounds in molecular modeling. Anticancer validation of pure compounds is needed to be able to strengthen the potential of compounds to be developed into candidates for anticancer drugs [4].

Based on the things that have been described, it is necessary to identify pure compounds from secondary metabolites from fermented Cladosporium sp. EN-S01. The sample suspected to contain anticancer activity need to be re-evaluated for their cytotoxicity against MCF-7 cancer cell lines.

\section{MATERIALS AND METHODS}

Fungal material

Cladosporium sp. EN-S01 was isolated from the marine brown algae Sargassum cinereum, collected from Pramuka Island, Kepulauan Seribu Marine National Park, Indonesia. This fungus was identified by morphological features, including the characteristic of ascospores and colonies. The pure cultures were deposited in the Laboratorium of Microbiology, Biology Department, Faculty of Mathematics and Natural Sciences, Universitas Padjadjaran.

Cultivation, extraction, and isolation of secondary metabolite

Cladosporium sp. EN-S01 was cultivated in $1 \mathrm{l}$ Erlenmeyer flask containing saline water, Potato Dextrose Broth, $\mathrm{CaCO3}$, yeast extract, and chloramphenicol. The culture was incubated at $25^{\circ} \mathrm{C}$ for $5 \mathrm{~d}$. The filtered broth was extracted with ethyl acetate then evaporated under vacuum in a rotary evaporator, to give $1 \mathrm{~g}$ of the dark brown viscous mass of the crude ethyl acetate extract. Crude ethyl acetate extract was subjected to column chromatography for further fractionation using n-hexane and ethyl acetate. After crystallization gave fine needles crystal.

\section{Infrared spectroscopy}

The sample for IR analysis was using $2 \mathrm{mg}$ of solid form sample, then crushed in small mortal together with $100 \mathrm{mg}$ of dried potassium bromide become pellet. The pellet was placed in the IR spectrophotometer sample area for further analysis.

\section{Cell culture}

MCF-7 provided by Biological Activity Test Laboratory, Central Laboratory, Universitas Padjadjaran. Human cancer cell line was maintained as monolayer cultures in RPMI, supplemented with $10 \%$ Fetal Bovine Serum and $1 \%$ of the antibiotic solution under an atmosphere of $5 \% \mathrm{CO}^{2}$ at $37{ }^{\circ} \mathrm{C}$. Cell was trypsinized confluent. A stock solution of the sample was prepared in $0,1,10,100$, and $1000 \mu \mathrm{g} / \mathrm{ml}$.

\section{Resazurin reduction assay}

The cytotoxic from a secondary metabolite of fermented Cladosporium sp. EN-S01 was evaluated through prestoblue technique. The assay 
was done with plated the cells in 96-multiwell culture plates at a density of $0.8 \times 10^{4}-1 \times 10^{4}$ cells/well. Twenty-four hours after plating, the medium was discarded, and fresh medium containing the sample at different concentrations $(1,10,100$, and $1000 \mu \mathrm{g} / \mathrm{ml})$ and control $(0 \mu \mathrm{g} / \mathrm{ml})$ was added. After $24 \mathrm{~h}$ incubation with the sample, the reagent of prestoblue was added at a final concentration of $0,5 \mathrm{mg} / \mathrm{ml}$ and incubated for $2 \mathrm{~h}$. The results are expressed as the percentage of cell proliferation relative to control (untreated cells) carried out in duplicate. Percentage of cell viability (CV) was calculated manually using the formula:

$\%$ Cell Inhibition $=100-$ Abs $($ sample $) /$ Abs $($ control $) \times 100$

Positive values (between 0 and 100\%) can be interpreted as inhibition of cell proliferation. A dose-response curve was plotted to enable the calculation of $\mathrm{IC}_{50}$. The $\mathrm{IC}_{50}$ values were determined using Probit analysis. $\mathrm{IC}_{50}$ corresponds to the concentration of the extract that decreases the number of viable cells by $50 \%$. In this case, the absorbance in control corresponds to $100 \%$ viability.

\section{RESULTS AND DISCUSSION}

IR spectrum analysis is needed to determine the presence of functional groups in a sample. The results of IR spectrum analysis of fermented Cladosporium sp. EN-S01 compounds is shown in wavenumbers 3350 and $3264 \mathrm{~cm}^{-1}$ indicate the $\mathrm{O}-\mathrm{H}$ stretch, so this compound has an $\mathrm{O}-\mathrm{H}$ functional group. In addition, there was a double bond which was marked by the stretch of $\mathrm{C}-\mathrm{H} \mathrm{sp} \mathrm{s}^{2}$ at a wave number of $3080 \mathrm{~cm}^{-1}$. The carbonyl group in this compound is characterized by a stretch of $\mathrm{C}=0$ conjugated at wave number 1688 $\mathrm{cm}^{-1}$. The absorption at wavenumber $1521 \mathrm{~cm}^{-1}$ is a typical area of $\mathrm{C}$ $=\mathrm{C}$ aril, absorption at wavenumber $817 \mathrm{~cm}^{-1}$ indicates the presence of $\mathrm{C}-\mathrm{H}$ outside the field. Uptake in the wave numbers 1521 and 817 $\mathrm{cm}^{-1}$ are characteristics of aromatic groups.

Test results of pure compounds on MCF-7 breast cancer cell lines with Presto Blue kits are shown in fig. 1. Pure compounds fermented by Cladosporium sp. EN-S01 has the effect of inhibiting proliferation of MCF-7 cell lines starting from a concentration of $1 \mu \mathrm{g} / \mathrm{ml}$ as much as $17.51 \%$. The percentage of inhibition of MCF-7 cell lines tended to increase to $23.38-26.20 \%$ when the concentration was increased to 10 or $100 \mu \mathrm{g} / \mathrm{ml}$, then continued to increase by $53.66 \%$ at a concentration of $1000 \mu \mathrm{g} / \mathrm{ml}$. The percentage of inhibition of proliferation of MCF-7 cell lines is in line with the increase in sample concentration.

The $\mathrm{IC}_{50}$ value is obtained from the calculation process with probit analysis from the concentration-response range and inhibition of pure compounds from fermented Cladosporium spEN-S01 for cell death in inhibiting proliferation of MCF-7 cancer cell lines. Confirmation of accurate numbers that can be read on the percentage curve can be seen that the $\mathrm{IC}_{50}$ value is in the concentration range of $100-1000 \mu \mathrm{g} / \mathrm{ml}$. The results of calculations and probit analysis obtained $\mathrm{IC}_{50}$ values of $746.03 \mu \mathrm{g} / \mathrm{ml}$.

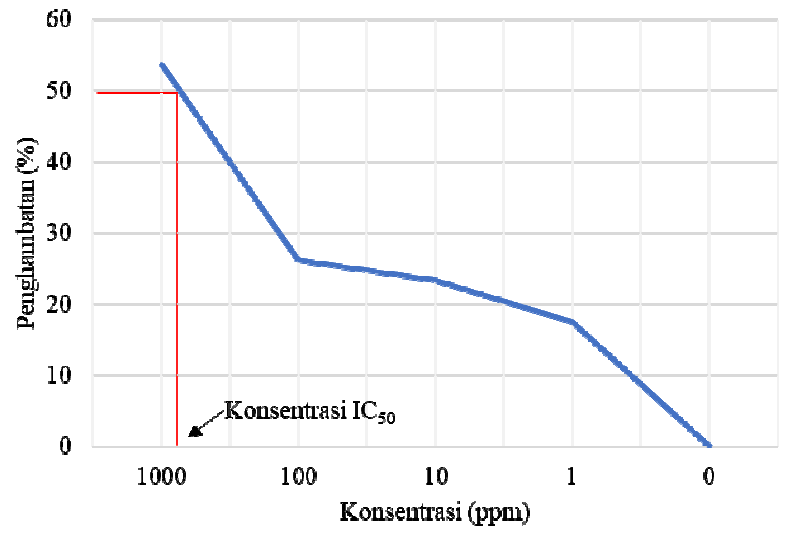

Fig. 1: Effect on antiproliferative of the aromatic compound from Cladosporium sp. En-S01 on MCF-7 cell line

Research on cytotoxicity test of Cladosporium spp. Fermented compounds. MCF-7 breast cancer cell lines have not been widely reported. Table 1 shows information on the cytotoxicity test of several compounds, supplemented by the results of this study as a comparison.

Tabel 1: Cytotoxicity of the compounds from endophytic Cladosporium spp.

\begin{tabular}{|c|c|c|c|c|c|}
\hline Species & Source & Compound & Assay & $\mathrm{IC}_{50}(\mu \mathrm{g} / \mathrm{ml})$ alley $(1988)$ & Refrence \\
\hline C. cladosporioides EN-399 & $\begin{array}{l}\text { Makroalga } \\
\text { Laurencia okamurai }\end{array}$ & Cladosporol H & MTT & 3,36 (active) & {$[5]$} \\
\hline C. cladosporioides EN-399 & $\begin{array}{l}\text { Makroalga } \\
\text { Laurencia okamurai }\end{array}$ & Cladosporol J & MTT & 4,06 (active) & [5] \\
\hline Cladosporium sp. KcFLg' & $\begin{array}{l}\text { Bakau } \\
\text { Kandeliacandel }\end{array}$ & Cladosporone A & Trypan Blue & $\begin{array}{l}7,50 \\
\text { (inactive) }\end{array}$ & [6] \\
\hline $\begin{array}{l}\text { Cladosporium sp. } \\
\text { EN-S01 }\end{array}$ & $\begin{array}{l}\text { Makroalga } \\
\text { Sargassum cinereum }\end{array}$ & Crude extract & MTT & $\begin{array}{l}8,46 \\
\text { (very active) }\end{array}$ & [3] \\
\hline $\begin{array}{l}\text { Cladosporium sp. } \\
\text { EN-S01 }\end{array}$ & $\begin{array}{l}\text { Makroalga } \\
\text { Sargassum cinereum }\end{array}$ & Aromatic compound & PrestoBlue & $\begin{array}{l}746,03 \\
\text { (tidakaktif) }\end{array}$ & Primary data \\
\hline
\end{tabular}

Li et al. (2017) isolate cladosporol $\mathrm{H}$ and cladosporol $\mathrm{J}$ from $C$. cladosporioides EN-399 from macroalgae Laurencia okamurai. Cytotoxic results using MTT assay showed that these compounds had $\mathrm{IC}_{50}$ values of 3.36 and $4.06 \mu \mathrm{g} / \mathrm{ml}$, respectively [5]. This value belongs to the active category according to Alley (1988). Ai et al. (2015) isolate cladosporone A from Cladosporium sp. KcFLg 'origin of mangrove Kandeliacandel. The cytotoxic test of these compounds uses trypan blue assay which basically coloring dead cells. The $\mathrm{IC}_{50}$ value obtained is $7.50 \mu \mathrm{g} / \mathrm{ml}$ and belongs to the inactive category. From the table, it can be shown that with the use of the prestoblue for sample of this study have $\mathrm{IC}_{50}$ values of $746.03 \mu \mathrm{g} / \mathrm{ml}$ in the very inactive category.

Cell viability and cytotoxicity of compounds or extracts were assessed through measurement of mitochondrial activity. The most common mitochondrial activity was detected using tetrazolium and resazurin reduction assay. Tetrazolium reduction assay, for example, MTT assay (3-(4, 5-dimethylthiazol-2-yl)-2, 5diphenyltetrazolium bromide), is an assay technique in the form of exposure to tetrazolium salts into cells after the incubation period after exposure of the test compound is complete. The exposure results are detected in colorimetry. Tetrazolium salt reacts with succinic dehydrogenase in the living cell mitochondria and produces purple formazan crystals. Because the crystals are insoluble, but colorimetric readings require dissolved formazan, then DMSO is described. This procedure is at risk of cytotoxic because if the DMSO concentration is overused. Resazurin (7hydroxy-10-oxidophenoxazin-10um-3-one) reduction assay, for example, prestoblue, is a water-soluble dye. Resazurin reacts with the enzyme NADPH/NADH to live cell dehydrogenase to become resofurin. Resofurn dissolves in water so that it can be detected directly in colorimetry or fluorometry. The technique of using shorter and non-cytotoxic resazurin against test cells is the reason this technique is superior to tetralozium [7]. 
Boncler et al. (2014) compared the results of a plant compound test on human umbilical venous endothelial cell lines (HUVECs) between MTT assay and prestoblue. The results of colorimetric measurements using prestoblue produce a higher response value. However, the colorimetric and prestoblue MTT response values were similar in flourometry. These results conclude that viability testing using prestoblue in colorimetry should be avoided. But the viability test using MTT and prestoblue fluorometry is recommended [7].

The crude extract from Cladosporium sp. EN-S01 has an IC50 value of $8.46 \mu \mathrm{g} / \mathrm{ml}$ against MCF-7 (Wulandari et al., 2018). This value includes a crude extract of strong anticancer potency but based on $\mathrm{IC}_{50}$ pure compound from fermentedCladosporium sp. EN-S01 is not included in the active compound category, even though the compound is a major compound from its crude extract.

Evaluating the bioactivity of a compound indicates whether the activity is caused by a single or mixed compound. During the evaluation process, if the activity of a compound is lost or reduced from the crude extract, the possibility of pure compound activity is related to the synergy between a number of compounds contained in the crude extract, which, when separated, is not individually activated [4]. Thus, the inactivity of this aromatic compound is because this compound is synergistic with a mixture of other compounds in crude extracts.

\section{CONCLUSION}

In summary, a pure compound of secondary metabolites from fungus Cladosporium sp. EN-S01 from marine macroalgae Sargassum cineuremhas a chemical structure of polyhydroxy aromatic. The IC50 value of pure compound fermented by Cladosporium sp. EN-S01 on MCF-7 breast cancer cell lines was 746.03 ppm, included in the inactive category. Further, investigations will be interesting to test the cytotoxic activity of compound against other cell lines and re-test with MTT assay.

\section{ACKNOWLEDGMENT}

The authors would like to acknowledge Academic Leadership GrantUniversitasPadjadjaran-2017 for providing the necessary funds to conduct the study.

\section{AUTHORS CONTRIBUTIONS}

Conceived and designed the experiments: APW, DH, PA, Performed the experiments: RRINE, Analyzed the data: APW, RRINE, DH, Wrote the paper: RRINE

\section{CONFLICT OF INTERESTS}

\section{Declared none}

\section{REFERENCES}

1. World Health Organization. Cancer country profiles-Indonesia. World Health Organization Cancer Control Program Department of Chronic Diseases and Health Promotion. Switzerland; 2014.

2. Sunil D, Kamath PR. In vitro bioassay techniques for anticancer drug discovery and development. CRC Press; 2017.

3. Wulandari AP, Examinati RRIN, Madihah, Huspa, D. H. P, Andrayaningsih P. Cytotoxicity of metabolites produced by endopytic fungus cladosporium sp. isolated from marine macroalgae on in-vitro MCF-7, HeLa, and DU-145 cell lines. Int J Pharm Pharm Sci 2018;10:72-6.

4. Sarker SD, Nahar L. An introduction to natural products isolation. Natural Products Isolation 2012;2:1-25.

5. Li HL, Li XM, Mandi A, Antus S, Li X, Zhang $\mathrm{P}$, et al. Characterization of cladosporols from the marine algal-derived endophytic fungus cladosporium cladosporioides EN-399 and configurational revision of the previously reported cladosporol derivatives. J Org Chem 2017;82:9946-54.

6. Ai W, Lin X, Wang Z, Lu X, Mangaladoss F, Yang X, et al. Cladosporone $A$, a new dimeric tetralone from fungus cladosporium sp. KcFL6'derived of mangrove plant Kandelia candel. J Antibiot 2015;68:213.

7. Boncler M, Rożalski M, Krajewska U, Podsędek A, Watala C. Comparison of prestoblue and MTT assays of cellular viability in the assessment of anti-proliferative effects of plant extracts on human endothelial cells. J Pharmacol Toxicol Methods 2014;69:9-16. 